Handbook of Historical Animal Studies 



\section{Handbook of Historical Animal Studies}

Edited by

Mieke Roscher, André Krebber and Brett Mizelle 
ISBN 978-3-11-053429-0

e-ISBN (PDF) 978-3-11-053655-3

e-ISBN (EPUB) 978-3-11-053436-8

Library of Congress Control Number: 2021931937

Bibliographic information published by the Deutsche Nationalbibliothek The Deutsche Nationalbibliothek lists this publication in the Deutsche Nationalbibliografie; detailed bibliographic data are available on the Internet at http://dnb.dnb.de.

(C) 2021 Walter de Gruyter GmbH, Berlin/Boston Cover Image: Double entendre, boy with pig attached to rope, by Briton Riviere (1840-1920), illustration from magazine The Graphic, volume XIII, no 329, March 18, 1876. DEA/BIBLIOTECA AMBROSIANA/ Kontributor/Getty Images.

Printing and binding: CPI books $\mathrm{GmbH}$, Leck

www.degruyter.com 